DOI https://doi.org/10.18551/rjoas.2017-12.21

\title{
RESEARCH OF THE PROFIT'S ESSENCE AS ECONOMIC CATEGORY ON THE EXAMPLE OF AGRICULTURAL ENTERPRISES
}

\author{
Jiang Genxiang, Master's Program in Economics \\ Vladivostok State University of Economics and Service, Vladivostok, Russia \\ Krasova E.V. ${ }^{*}$, Candidate of Economic Sciences \\ Vladivostok State University of Economics and Service, Vladivostok, Russia \\ *E-mail: elena krasova@rambler.ru
}

\begin{abstract}
Research of the essence and nature of profits is the oldest question that the world economic science is studying till present days. Scientists of various fields and scientific schools have made a significant contribution to researches of profit's nature; however, modern life again raises this issue. The main scientific and practical problem of the article is the incompleteness in the process of cognizing the nature of profit, its practical importance for enterprises. The purpose of the article is to study the profit's nature and discover its essence on the basis of existing concepts and on the example of agricultural enterprises as the most important representatives of real sector of economy. The methodological basis of the research is the theses of classical economic theory, neoinstitutionalism, modern finance theory, fundamental foundations of the enterprise's economy, theory of modern accounting. In the article, relevance of the research's subject is considered, excursion into the history of research of profit's essence is made, a number of definitions of category "profit» are studied, and classification of profit's types for agricultural enterprises is given. Also, the article highlights the functions and factors that influence the formation of profit (on the example of agricultural production), presents a simple algorithm for calculating profits, which does not infringe any of the existing profit's concepts.
\end{abstract}

\section{KEY WORDS}

Profit, profit's essence, profit's nature, financial results, profit.

In modern conditions of development, the most important indicator of the efficiency of any enterprise is its effectiveness, which consists of several components of financial and economic activity. The most important and well-known components are revenue, costs, turnover, yield, investment. The final indicator, reflecting the overall profitability and effectiveness of the activity, is profit.

Research of profit both at the deep theoretical level and at the level of a particular enterprise is the basis for making scientific decisions at all levels of management - national, regional, individual enterprise level. Study of the nature of profit, features of its management is aimed not only to reveal the fundamental aspects of profit formation and its maximization, but also to reveal the opportunities for further growth of the agro-industrial complex and economy as a whole. In these conditions, the importance of modern theoretical analysis, disclosing the whole diversity of the concept of "profit» as one of the most important economic category, increases.

During a number of years, representatives of economic school have explored and put forward many different theoretical aspects of understanding and generating profit. Profit is one of the most intricate and complex economic categories, therefore we will give its various definitions, interpretations, representations. In general sense, profit is the amount which revenue exceeds costs. Very often only profit is defined as the difference between total revenue and total costs or as net revenue. 


\section{RESULTS AND DISCUSSION}

Today there are many definitions of profit, its types and functions. The founders among researchers of profit's essence are the economists of classical economic school and their followers: Adam Smith, Jean-Baptiste Say, Johann Heinrich von Thunen, Karl Marx, Frank Knight, John M. Keynes, John C. Galbraith and others [1]. When we consider their concepts of entrepreneurship, we can note the following main directions of the theory of entrepreneurs' profit: unpaid labor of workers (K. Marx); temporary income from technical innovations (J.A. Schumpeter); result of the uncertain nature of future events (F. Knight, J. M. Keynes); profit as income generated by the existence of monopolies that determine the difference between price of goods and their production costs [2].

Researches of modern scientists also include different approaches to study of profit's nature. N.N. Seleznev and A.F. lonova in their work examine the impact of inflation on financial results, but does not analyze the correspondence between the concepts of financial result and profit. The authors provide the following definition of profit: profit is the earnings of entrepreneur in cash, which characterizes his remuneration for risk of entrepreneurial activity. Also we can find such definition: profit is the difference between aggregate income and total costs in the process of entrepreneurial activities. Profit is a special systematically reproduced resource of commercial organization, the final goal of business development [3]. So we can note that profit's definition has extensive characteristics because it is a special resource, net income and the final goal of business development.

According to definition of S.F. Pokropivniy, profit is a part of the revenue that remains after recovering all costs for the enterprise's production and commercial activities [4]. According to other scientists, this definition reveals its economic essence not completely, and they give their definition of profit as a monetary expression of the monetary savings created by enterprises of any form of ownership [5;6].

G.V. Savitskaya notes that the financial results of enterprise's activities are characterized by amount of received profit and by level of profitability: profit is a part of the net income that business entities receive after their products are sold. The profit is subdivided into balance (cumulative), taxable and net profit. Balance sheet profit includes financial results from the sale of products, works and services, from other sales, income and expenses from non-operating transactions. Taxable profit is the difference between the balance sheet profit and the amount of profit taxable on income, as well as the amount of benefits for income tax. Net profit is the profit that remains after payment of all taxes, economic sanctions and deductions to charitable funds [7].

A.N. Ryakhovskoy with colleagues interprets profit as a part of newly created value, which is produced and realized, and is ready for distribution. The author notes the importance of process of selling product, not just producing [8].

According to opinion of V.Y. Gorfinkely and his colleagues, profit characterizes the economic effect obtained in result of the enterprise's activities. The presence of profit in enterprise means that its revenues exceed all costs associated with its activities [9]. A.M. Kovaleva in her works pointed out that, in accordance with the economic approach, profit is increase of the capital of enterprise's owners [10].

After analysis of definitions of profit, we can conclude that profit is any benefit. Nevertheless, these definitions of profit make it rather difficult to understand it as an economic category. I.A. Blank, analyzing the monetary mechanisms of managing the formation of operating profit, characterizes the balance (total) profit as one of the important results in financial activities of enterprise. This is the sum of the following types of enterprise's profits: profit from sale of products (or operating profit), profit from sale of property and profits from non-operating transactions with the key role of operating profit, whose share currently amounts to approximately $90-95 \%$ of the total profit [11].

Applying research of profit's nature to agricultural enterprises, we should note that future of Russian economy depends to a large extent on reliability of information that provides a real reflection of the financial situation and financial performance of agricultural organizations. Profit as a criterion of the effectiveness of agricultural reproduction, has one 
important feature - it reflects the final financial result of agricultural producers [12].

From the point of view of modern accounting, profit is a form of monetary accumulation that is formed in all sectors of national economy and describes the final financial result of the business activities. Modern national financial policy of developed and developing countries in development of accounting forms is aimed to improving indicators, it is important to understand the types of profits in terms of accounting approach [13].

The types of profit are reflected, as a rule, in report of financial results of enterprise. However, the variety of types of profit is much wider and depends on the industry's kind, type and scale of enterprise. The systematization of types of profit for agricultural sector is presented in table 1.

Table 1 - Generalized classification of profit's types of agricultural enterprise by its functional purposes

\begin{tabular}{|c|c|}
\hline Classification features & Profit's types \\
\hline \multirow{7}{*}{ According to Accounting } & Gross profit \\
\hline & Revenue from sales \\
\hline & Profit before taxation \\
\hline & Taxable profit \\
\hline & Net profit \\
\hline & Basic profit per share \\
\hline & Total profit per share \\
\hline \multirow{3}{*}{ By sources of formation } & Profit from sales of agricultural products \\
\hline & Profit from sales of farm property \\
\hline & Profit from non-sales operations \\
\hline \multirow{6}{*}{ By type of economic activity } & Profit from the sale of products \\
\hline & Profit from natural events \\
\hline & Profit from agricultural activities \\
\hline & Profit from investing activities \\
\hline & Profit from financing activities \\
\hline & Profit from innovation activities \\
\hline \multirow{5}{*}{ By composition of components } & Marginal profit \\
\hline & Revenue from sales \\
\hline & Profit before taxation \\
\hline & Undistributed profit of current period \\
\hline & Net profit \\
\hline \multirow{4}{*}{ By direction of distribution of net profit } & Capitalized profit \\
\hline & Profit belonging to owners \\
\hline & Profit allocated to reserve funds \\
\hline & Profit remaining at the disposal of enterprise \\
\hline \multirow{2}{*}{ By terms of taxation } & Taxable profit \\
\hline & Nontaxable profit (according to tax privileges) \\
\hline By nature of inflationary cleaning & $\begin{array}{l}\text { Nominal profit } \\
\text { Real profit }\end{array}$ \\
\hline \multirow{3}{*}{ Depending on time of formation of profit } & Profit from past periods \\
\hline & Profit of current period \\
\hline & Profit of planned period \\
\hline \multirow{3}{*}{ Depending on regularity of formation } & Emergency profit \\
\hline & Regular (periodic) profit \\
\hline & Seasonal profit \\
\hline \multirow{2}{*}{ By value of final result } & Positive profit \\
\hline & Negative profit (loss) \\
\hline \multirow{3}{*}{$\begin{array}{c}\text { From the position of adequacy of formation of } \\
\text { the profit's level }\end{array}$} & Low profit \\
\hline & Normal profit \\
\hline & High profit \\
\hline \multirow{3}{*}{ From the position of uncertainty and risk } & Profit taking into account the risk \\
\hline & Compensatory profit \\
\hline & Appropriated profit \\
\hline From the point of view of bankruptcy & Sanitation Profit \\
\hline
\end{tabular}

The variety of profit's types extends the possibilities of analyzing the activities of economic entities that can classify, detail and use the profit indicator in various situations. Of course, the correctness of calculation of taxable profits will be important for the tax authorities, and for the owners of enterprise the most important thing is net profit as a source of accrual and payment of dividends.

The nature of profit as economic category, specific way of expressing its properties is 
manifested in functions of profit. We consider the following profit's functions [14; 15]:

- evaluation function. Profit is considered as indicator that most comprehensively characterizes the efficiency of production and assesses the economic activity of enterprise. In agriculture the evaluation function plays very important role;

- stimulating function. Profit promotes expansion of production, social development, material encouragement of agricultural producers and their employees, and also has a stimulating effect on the functioning of enterprises. The peculiarity of agricultural enterprises is the fact that profits are distributed mainly in favor of development of production, or for needs of capital's accumulation, not consumption;

- fiscal function. Profit is considered as a source of formation of budgetary resources and off-budget funds. The profit of agricultural producers is more often privileged in tax, but it is the basis for filling local budgets;

- control function. Profit is the main indicator that shows the final result of the enterprise's activity;

- distribution function. Profit is distributed between production and non-production spheres, between enterprises and society, owners and employees. Distribution function is a source of accumulation and development of agricultural production, consumption, material incentives for workers;

- social function. Profit is a source of funding for social needs, social programs, and charitable activities;

- protective function. Profit is similar to the enterprise's shield, protecting against the danger of bankruptcy. In real life the probability of bankruptcy of agricultural enterprise can manifest itself even in the conditions of positive profit. With a competent financial management of enterprise with accumulated reserves, profits can exit the crisis more quickly and successfully. By means of accumulating the profits enterprise can quickly build up highly liquid assets, the amount of its own funds, form reserve and insurance funds, etc.

Thus, profit as economic category has a large number of qualifying characteristics. The main economic essence of profit is characteristic of the financial result of enterprise's activity, also is the basis of enterprise's economic development and the main source of expanded reproduction.

The formation of profit depends on many factors. These factors can be internal and external, can depend on own activities of enterprises or not. Factors affecting the profit and profitability of agricultural production are numerous and diverse. Some of them depend on the activities of specific collectives, others are related to technology and the organization of production, the efficiency of use of productive resources. The main factors affecting the profit and profitability of agricultural enterprises are the following [15; 16]:

1) level of production costs. The cost directly depends on level of manufacturability of agricultural production, the quality of management in production process, labor costs, quality of ecology in production, formed production infrastructure;

2) weather and climate conditions. The big role of the weather factor is manifested in plant growing. The emergence of productive and lean years in the history of agriculture was associated with climatic changes;

3) average prices in markets. The agricultural market has a special mechanism for pricing, responsive to changes in demand and exposed to government regulation. Currently, large share of agricultural enterprises of all forms of ownership in different countries have low profitability, which is due to the state of the world food market. However, substantial government support allows to survive and develop this market. This support is expressed in establishment of minimum prices for agricultural products, tax privileges, subsidies, grant support and other methods.

For agricultural enterprise that oriented to rigid competitive market, the condition of the activity's efficiency is to establish acceptable minimum price for enterprise and to ensure the optimal volume of output, which gives the maximum amount of profit. In conditions of price competition, production that ensures a minimum cost of its products and, accordingly, a maximum of profit, can be considered as effective. In conditions of non-price competition, 
agricultural production is effective, if it ensures minimum total costs, or maximum aggregate productivity of labor.

Thus, the main factors that determine the value of agricultural products in a competitive market include «market pressure» on the price of goods in the direction of reduction and forced «producer pressure». To compare the variants of technology and other strategic measures, the entrepreneur always focuses on market prices. To enter the market successfully, enterprise needs to have a technology that may not be the most modern. It is enough to reduce costs relative to competitors that dominate the market [17].

In dynamic process this profit can be determined by the formula:

$$
\begin{gathered}
P=(P-C) Q T \\
\text { or } \\
P=\sum(P j-C j) Q j
\end{gathered}
$$

where $\mathrm{Pj}$ - the actual price of sale of goods in the market on the j-th time interval; $\mathrm{Cj}$ - prime cost of production of goods at the enterprise on the j-th time interval; $Q j$ - quantity of output on j-th time interval (month, year); $\mathrm{T}$ - the number of periods of time in the conditions of leading decline in the level of the individual product cost relative to the price of goods on the market.

During comparing the variants of organizational and technical measures, this indicator can be considered as the relative savings received with its implementation. Therefore, the earlier the new technology are introduced, the cheaper they provide the output in comparison with the existing costs, the larger output, the longer the lead time and the greater personal income of the commodity producer [2].

\section{CONCLUSION}

The study of the profit's essence allows to draw the following conclusions.

1. Profit is a complex, intricate and completely unexplored economic category, characterized by a multitude of classification characteristics. Researchers of the past and modern scientists differently interpret the essence of profit; however, everything boils down to one: profit characterizes the financial result of enterprise's activities. Also profit is the basis of enterprise's economic development and the main source of expanded reproduction.

2. Agricultural enterprises are a special type of commodity producers whose activities depend on a number of specific factors, such as weather, climate and technological conditions. This fact reflects on the special pricing mechanism in this market, on profit formation, enterprise's development efficiency and distribution.

3. At present days the dominant form of agricultural markets is the combination of competitive and non-competitive markets, where a combination of price and non-price methods of competition occurs. Therefore, to maximize profits, agricultural producers must monitor the external environment, dynamically changing the direction of domestic policy under the influence of external factors.

\section{REFERENCES}

1. Sinelnik L.V. (2014). History of economic doctrines: the textbook. Moscow: Publ. house Knorus. 288 p.

2. Osipov V.A., Embulayev V.N. (2012). Profit as the goal of developing and making managerial decisions in business structures // Internet Journal of Science. №4 (13). pp. 48-54.

3. Ionova A.F., Selezneva N.N. (2010). Financial management: the textbook for retraining of accountants and auditors. Moscow: Publ. house Prospect. $592 \mathrm{p}$. 
4. Pokropivnyy S.F. (2013). Economics of enterprise: the textbook for students. Kiev: Publ. house KNEU. 271 p.

5. Economics of enterprise (organization) (2015). Edited by V.Ya. Pozdnyakova, O.V. Devyatkina. Moscow: Publ. house INFRA-M. 640 p.

6. Derbush N.M., Krasova E.V. (2016). Management of current assets as a part of the financial policy of a modern enterprise. // Fundamental research. №12-5. pp. 1071-1075.

7. Savitskaya G.V. (2014). Theory of the analysis of economic activity: the textbook. Moscow: Publ. house INFRA-M. 303 p.

8. The economy of the firm (2015). Edited by A.N. Ryakhovskoi. Moscow: Publ. house MASTER. $512 \mathrm{p}$.

9. The economy of the enterprise (firm) (2013). Edited by V.Ya. Gorfinkel. Moscow: Publ. house Prospect. $640 \mathrm{p}$.

10. Kovaleva A.M., Lapusta M.G., Skamay L.G. (2011). Finance of the firm. Moscow: Publ. house INFRA-M. $522 \mathrm{p}$.

11. Blank I.A. (2011). Management of financial resources. Moscow: Publ. house Omega-L. $768 \mathrm{p}$.

12. Rakhmatullin Y.Y. (2015). The main stages of historical development of profit accounting in agricultural enterprises // Herald of the Agrarian and Industrial Complex of Stavropol. No. 1 (17). pp. 348-351.

13. Dolgopolov O.V. (2015). A critical analysis of the definitions of incomes and expenditures that make up the modern paradigm of profit in financial accounting // Economics and Politics. No. 1 (4). pp. 30-36.

14. Gorelkina I.A., Kazakova Yu.O. (2009). Formation of profit in agricultural enterprise and directions of its improvement // The Financial Herald. No. 1 (19). pp. 21-25.

15. Shegurova V.P., Shibileva O.V. (2015). Optimization of structure of agricultural production // Bulletin of the Volzhsky University. No. 3 (34). pp. 246-250.

16. Dzagazhdova L.A., Miroshnikova T.K. (2014). Planning profit and profitability of agricultural enterprises // Economics and Management in the XXI Century: Development Trends. No. 19-1. pp. 171-175.

17. Osipov V.A. (2012). Profit of the entrepreneur: the essence and feedback in the management of organization // Territory of New Opportunities. Bulletin of the Vladivostok State University of Economics and Service. №3. pp. 108-119. 